\title{
INCREASING ENDURANCE IN PHYSICAL EFFORT BY ADMINISTRATION OF INOSINE
}

\author{
CĂTĂLIN PĂUNESCU ${ }^{1 \#}$, GABRIEL PIȚIGOI ${ }^{1 \#}$, GERMINA COSMA ${ }^{2 *}$, SILVIU MIREL PIȚURU ${ }^{1}$, \\ VASILICA GRIGORE ${ }^{3}$, SILVIU PETRESCU ${ }^{1 \#,}$, MARIA LILIANA MIRCICA ${ }^{1}$, MIHAELA \\ RĂDULESCU ${ }^{4}$, ALEXANDRU COSMA $^{2}$, RAMIN REZAEE $^{5}$, OANA CRISTINA PETRESCU $^{1}$
}

\author{
1 "Carol Davila" University of Medicine and Pharmacy, 37 Dionisie Lupu Street, Bucharest, 020022, Romania \\ ${ }^{2}$ University of Craiova, Physical Education and Sport Faculty, 156 Brestei Street, Craiova, 200207, Romania \\ ${ }^{3}$ National University of Physical Education and Sport, 140 Constantin Noica Street, Bucharest, 060057, Romania \\ ${ }^{4}$ University of Economic Studies, 2-10 Căderea Bastiliei Street, Bucharest, 010615, Romania \\ ${ }^{5}$ Clinical Research Unit, Faculty of Medicine, Mashhad University of Medical Sciences, Mashhad, Iran
}

*corresponding author: germinacosma@yahoo.com

${ }^{*}$ Authors with equal contribution.

Manuscript received: February 2020

\begin{abstract}
The use of banned substances in order to increase the performance capacity is one of the most widespread problems in the entire sports world. This study intended to provide an alternative for sustaining intense training or a training with a high-load of competitive means. Particularly, performing martial arts require good endurance to accomplish the technical actions under the normal parameters where the body may lose energy, vitamins, and many minerals. The present qualitative study assessed the impact of a dietary supplement containing inosine, on performance in 30 athletes, with a competitive experience of about $6-8$ years. The objective was to establish the level of endurance at different times for athletes who practice martial arts in both full contact and semi-contact systems. Thus, depending on the type of sport practiced, results recorded in the endurance tests, following the administration of inosine based supplements, showed an improvement in the athletes who practice a martial art of full contact type that requires a good endurance to perform technical actions in speed-strength regime.
\end{abstract}

\section{Rezumat}

Studiul de faţă reprezintă o cercetare calitativă cu privire la utilizarea suplimentelor alimentare pentru a crește performanțele în cadrul antrenamentelor sportivilor de performanță. Cercetarea s-a realizat pe 30 de sportivi, cu o experiență competițională de aproximativ 6 - 8 ani. Utilizarea substanţelor interzise în scopul creşterii capacităţii de performanţă reprezintă una dintre cele mai răspândite probleme din întreaga lume sportivă. Scopul acestui studiu este de a oferi o variantă de susţinere a antrenamentelor intense prin utilizarea inosinei ca supliment nutritiv. Aceste antrenamente cer o rezistență bună pentru a desfășura acțiunile tehnice în parametri normali, corpul consumând energie, vitamine și minerale. În studiu s-a urmărit nivelul anduranței în diferite momente pentru sportivii ce practică artele marțiale atât în sistem full contact cât şi semicontact. Studiul a evidenţiat că administrarea inosinei ca supliment nutritiv a crescut rezistența sportivilor care execută acțiuni tehnice full contact în regim de viteză-forță.

Keywords: inosine, dietary supplements, sports performance, endurance

\section{Introduction}

Trainers and athletes have always looked for ways to improve their performance to achieve success in competitions [1], one of such approaches is provision of the physiological requirements [2]. The concept of "food supplement" is relatively new as it was introduced to the field of food and nutrition in the last two decades of the 20th century [3].

The legislative foundations for food supplements were laid in the United States after a constructive dispute between the Food and Drug Administration (FDA), supplement manufacturers and consumer representatives. This led to establishment of "Dietary Supplement Health and Education act of 1994" to regulate dietary supplements, by considering them as food and not medicines.

At European level, the first legislative act with reference to food supplements, was "Directive 2002/46/EC of the European Parliament and of the Council of 10 June 2002" [4].

Food supplements are intended for oral consumption (administration) by healthy people who require higher exogenous intakes due to specific nutritional requirements related to physiological status, age (children, adolescents and senior citizens), intense physical activities etc. [3].

Experts on high performance sport define it as specific sportive activities usually competitions where athletes are ranked by a number or a rating scale value [5]. 
Most sports involve a certain form of endurance, and the type of endurance developed (at low or high intensity) can substantially affect the performance [6]. Since ancient times, certain substances have been used to boost body's physical and mental performance [7]. The dietary regime recommended for endurance athletes involves high protein and carbohydrate consumption, but very low fat intake together with the consumption of certain key micronutrients such as iron, calcium, and essential fatty acids [8]. The right dietary supplements vary based on the body type, age and sex, as well as the athlete's lifestyle and diet [9].

The use of doping pharmacological agents is one of the major negative aspects in sports, that must be carefully monitored [10].

Aerobic endurance exercise improves cell oxidative capacity possibly via increasing mitochondrial oxidative enzymes levels and boosting cellular insulin sensitivity in geriatrics [11].

Endurance athletes are at particular risk for dehydration, primarily because of increased fluid loss via sweating as a result of prolonged and intensive periods of exercise [8].

A research done within the International Athletics Federation, from 2005 to 2007 , reports that $85 \%$ of top athletes and $91 \%$ of endurance runners used supplements [12].

Scientific investigations have focused on a variety of ergogenic aids that may improve aerobic and anaerobic performances [13]. An important aspect in regulating human metabolism and energy expenditure is represented by chrono-nutrition and the temporal regulatory pattern of activity-feeding-resting relationship [16]. In the early 1980's, Russian and Eastern Bloc weight-lifters began to experiment with inosine supplementation, and as a result, many anecdotal claims about its ergogenic effect on strength, surfaced [13]. Inosine has a number of potentially important roles that may enhance training and/or exercise performance [14]. Inosine is produced in the human body, and its chemical structure is related to adenosine, which is included in adenosine triphosphate (ATP) as the energy source during the work done by each muscle; this product is popular with athletes who focus on endurance, as well as strength sports performance [15].

This supports the functioning of the cardiovascular system and through provision of oxygen and nutrients to the muscle; it increases the oxygen supply to the muscle tissue. Currently, inosine is widely touted by several companies as an effective energy booster, based on testimonials and rumours, has been used by Russian and Eastern Bloc athletes [17]. The principles of quality nutrition and the use of special nutritional supplements are valid for all sports, but the type of effort made must be taken into account. Consequently, prolonged inosine supplementation does not appear to improve aerobic performance and short-term power production during cycling and may actually have an ergolytic effect under some conditions [13, 18].

Dragan et al. [19] showed that 6-week inosine supplementation improves motoric speed conductibility of the popliteus nerve of Olympic weightlifters, but they reported no performance data. Although marketing claims [20] suggest that inosine benefits athletes involved in anaerobic as well as aerobic events, little if any empirical data exists to support these claims. Excessive use and/or prolonged misuse has no ergogenic effects, but may cause possible health problems if taken over long periods of time; uric acid concentration was shown to increase significantly after days 6 and 11 [21].

Herbal dietary supplements are taken by physically active individuals for a variety of reasons, including increasing energy, losing weight, promoting muscle growth, or inducing other physiological or metabolic responses that may enhance exercise performance [22]. However, sports nutrition products are not an appropriate substitute for a varied and balanced diet which is best suited for children and adolescents.

In this study, the impact of inosine as a dietary supplement on performance in athletes practicing martial arts, was assessed.

\section{Materials and Methods}

Study design

A total of 30 athletes of both sexes practicing martial arts, who volunteered to participate, were enrolled in this study. At the time of testing, all athletes had a break of competitive training for at least two months.

All procedures related to this study were performed in the gym of the Physical Education and Sports Department within the University of Medicine and Pharmacy "Carol Davila", Bucharest, Romania. The participants completed a questionnaire on medical history and signed a written consent for testing. The present study was conducted in one week.

Study protocol

The test protocol consisted of the following three endurance-focused tests:

Test 1: motor reaction to visual stimulus (maximum number of different motor actions executed at the same speed and intensity), measured by Kinovea video analysis program; test 2 : simulated combat based on specific time frame, depending on the sport (different technical actions executed, depending on the specific regulation, on mobile targets on both attack and counter attack), measured by Kinovea video analysis program; test 3: force exerted on the mean circular action performed with a lower member, upon choice (this test was not performed for the practitioners of wkf karate, being a semi-contact sport) - measured by an electronic jacket, Daedo, Gen 1 PSS Electronic System, placed on the dummy, with Gen 2 E-Foot Gear Protector for athletes, and connected to a computer 
with standard ring management software for use with True score wireless systems Daedo Gen1 Software upgrade, which can be adapted according to the weight category.

All athletes were initially evaluated following a threeday break. On the fourth day, they got two capsules of inosine (500 mg of inosine per capsule) in one administration, approximately 30 minutes before the exercise, followed by 15 minutes warm up and the final evaluation. The dose of the administered dietary supplement with one gram inosine has the following characteristics: energy value $3.4 \mathrm{~kJ} / 0.8 \mathrm{kcal}, 0.2 \mathrm{~g}$ of proteins [16].
Competitive efforts were made during the training, only after analysing the competitions types and their number. These kinds of effort are very important at the end of the preparatory and competitive phase, largely determining the rate of sports performance enhancement.

The measurements and evaluations were done using the following tools: Pulse Oximeter, Polar A 370 and Kinovea video analysis program. Statistical analysis was performed using SPSS, version 23.

Figure 1 provides an overview of the three tests performed in our study.

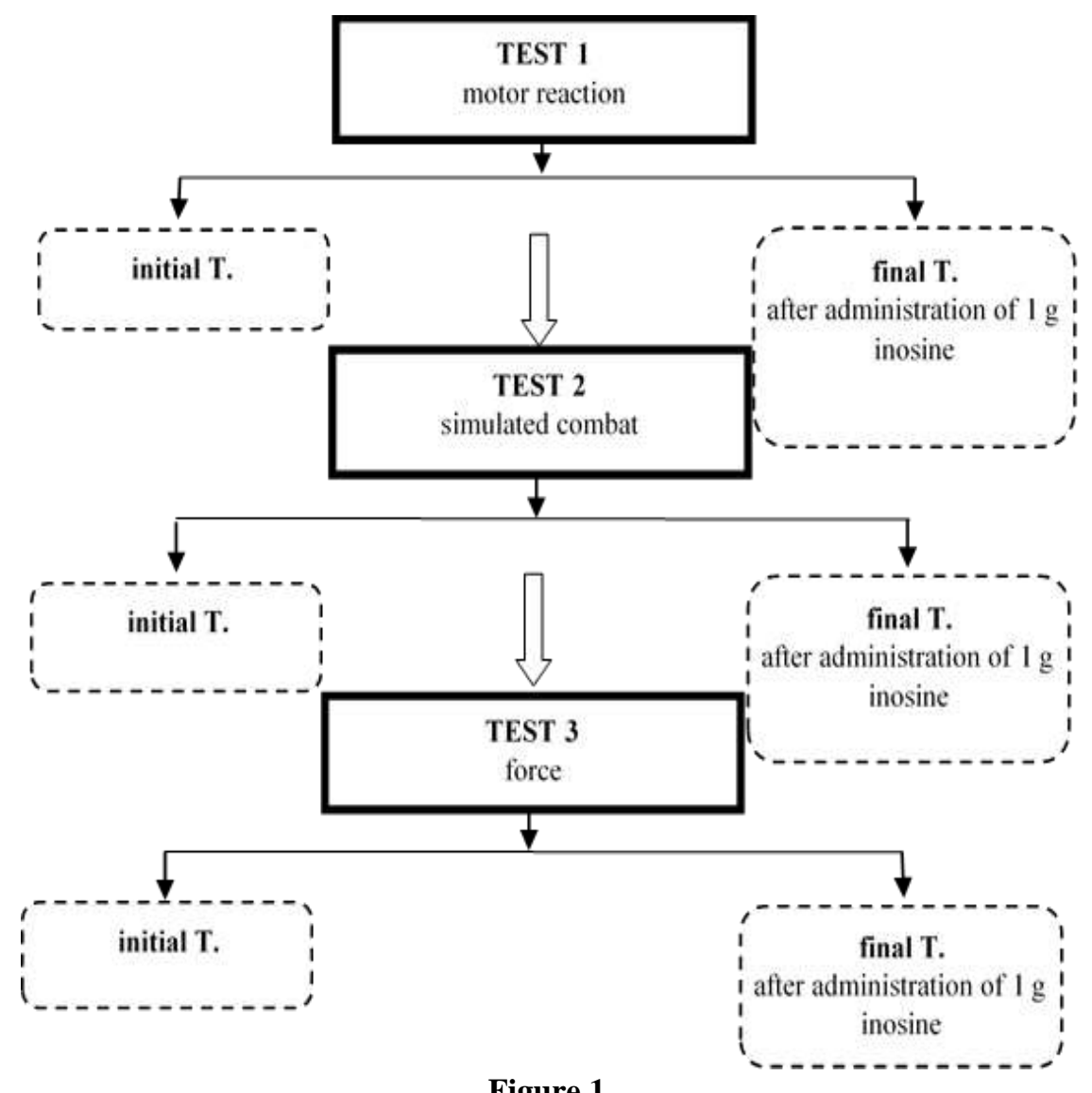

Figure 1.

Viscosity curves and the statistical mean of differences expressed by the regression lines

\section{Results and Discussion}

Our results revealed that administration of $1 \mathrm{~g}$ inosine, according to the sport practiced, produced some significant differences.

A total of 30 athletes of both sexes (age (mean \pm SD) $23.3 \pm 1.9$ years; height (mean $\pm \mathrm{SD}) 170.6 \pm 9.1 \mathrm{~cm}$; and body weight (mean $\pm \mathrm{SD}$ ) $65 \pm 12.2 \mathrm{~kg}$ (Figure 2)) practicing martial arts, who volunteered to participate, were enrolled in this study; all participants had a competitive experience of about 6 - 8 years, 10 practiced taekwondo wt, 10 karate wkf and 10 ashihara karate.

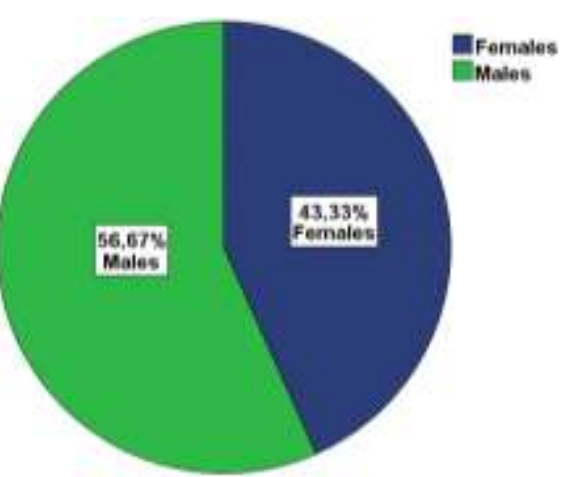

Figure 2.

Study population 
Based on the Pulse Oximeter test results, at the final test, the peripheral oxygen saturation $(\mathrm{SpO} 2)$ was higher by $2 \%$, after mixed/anaerobic effort and by only $1 \%$ after aerobic type. As shown in Figure 3, the time spent in the exercise zone increased after inosine administration. The analysis of the data showed that this increase was significant, on mean by 18 seconds, for the specific competitive effort.

As can be seen in Figure 4, after administration of $1 \mathrm{~g}$ inosine, the time spent in the exercise area increased and the average heart rate increased from 146 to 162 beats/min, so athletes could sustain greater effort.

At the final test, after administration of inosine, an increase of $14-15 \%$ in the number of technical actions for the test of motor reaction to the visual stimulus (Test 1), was observed (Figure 5).

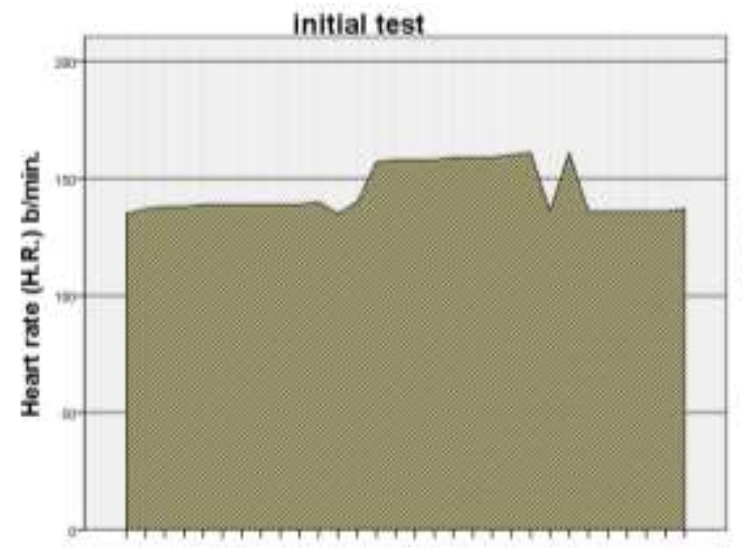

athletes

Figure 4.

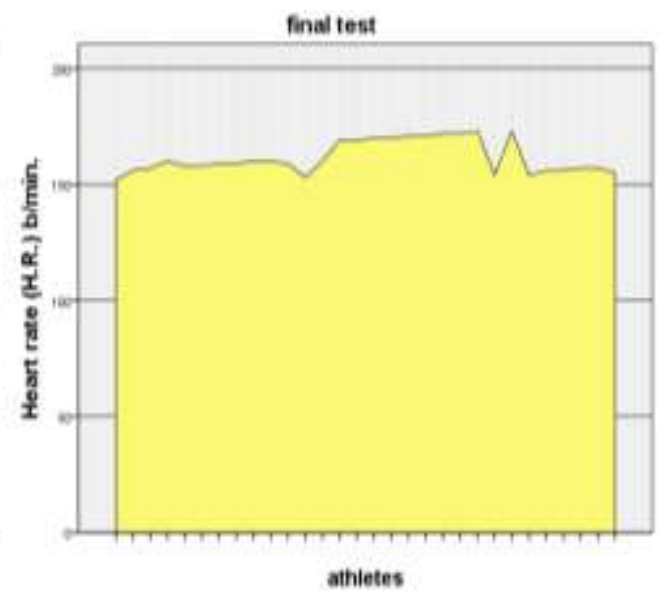

The evolution of the average heart rate in specific competitive effort Test 2
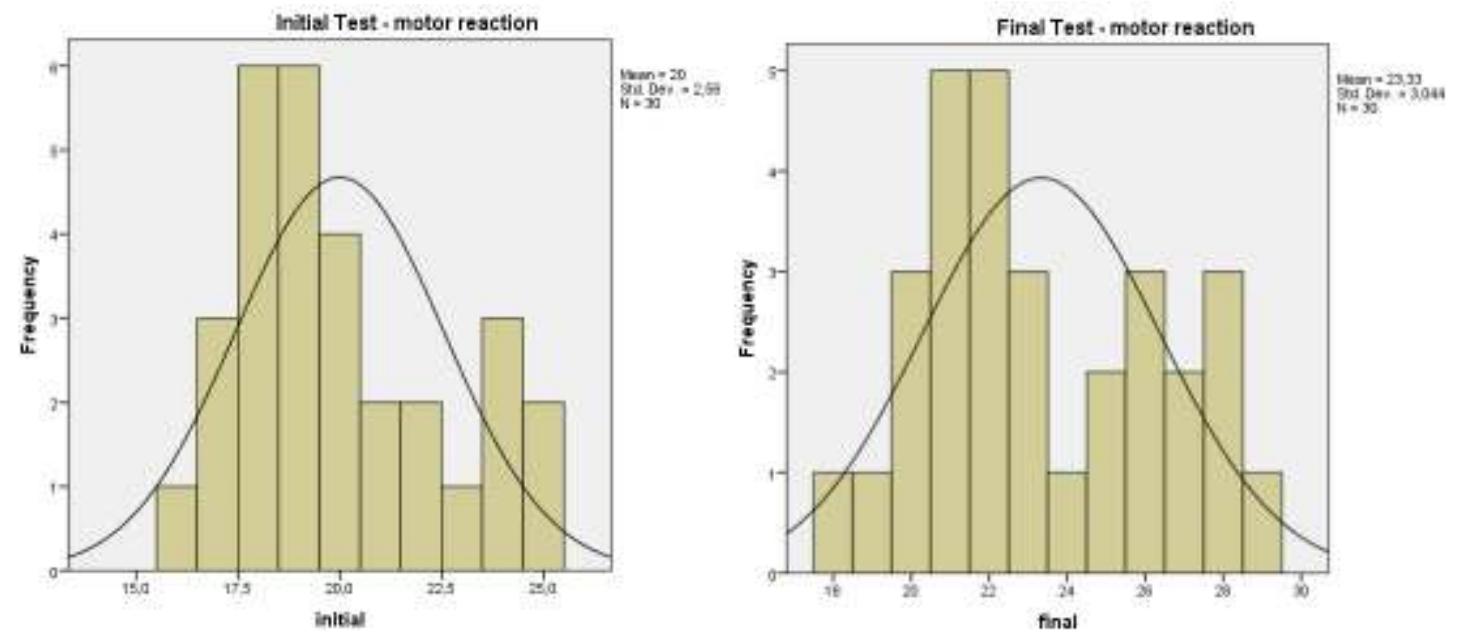

Figure 5.

The number of technical actions performed on the motor reaction -Test 1

The mean number of technical actions (Figure 6) increased from $72.67 \pm 46.73$ in the initial test to $97.67 \pm 66.26$ after administration of inosine, showing a bidirectional level of significance $(\mathrm{p}<0.01)$. The

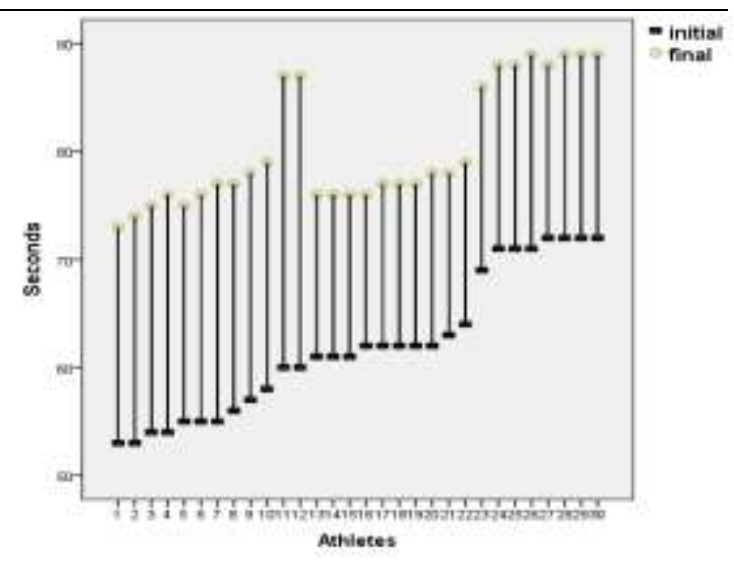

Figure 3.

Time spent in the area of specific competitive effort 


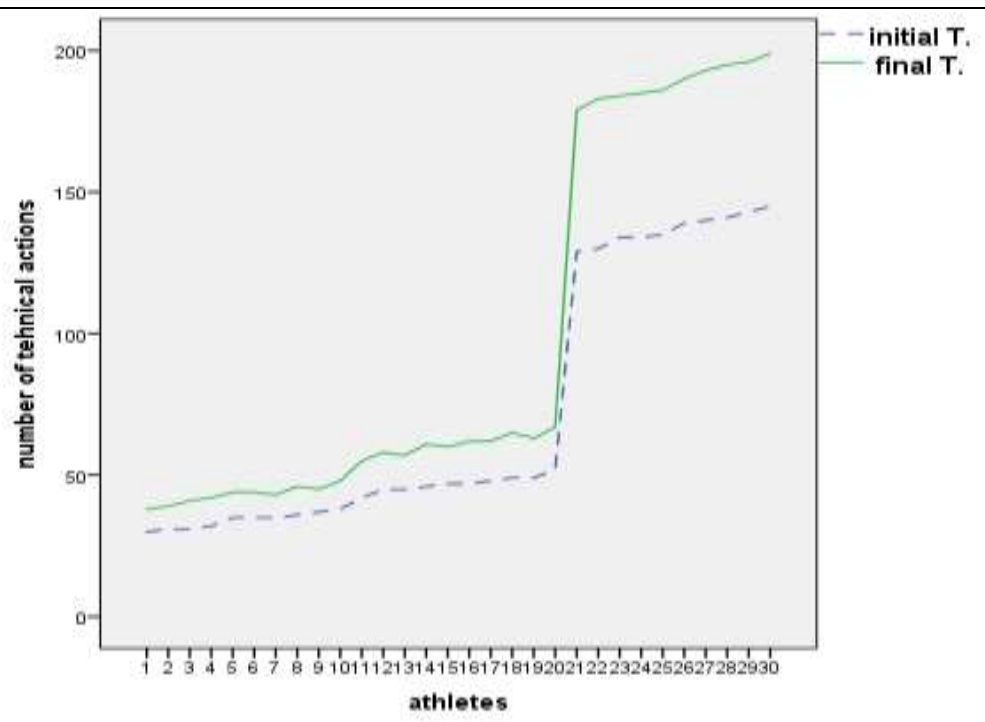

Figure 6.

The number of technical actions performed during specific competitive effort (Test 2)

In the strength test, only the athletes from the two full contact sports were investigated. Thus, after the administration of inosine, there were increases of $24 \%$ for taekwondo and $22 \%$ for ashihara in the number of executions (Figure 7).

There is data supporting the fact that athletes use a variety of dietary supplements from both natural and organic sources, to increase energy levels, maintain endurance, health and immune system functioning, improve performance and prevent nutritional deficiencies that compromise health [23].

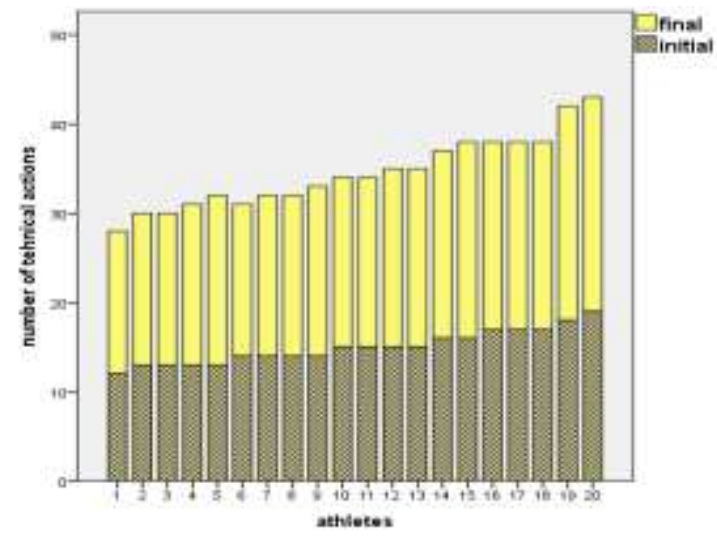

Figure 7.

The number of technical actions performed at medium level with constant force (Test 3)

As an endogenous purine nucleoside, inosine produced following formed adenosine breakdown adenosine deaminase, is released into the extracellular space during metabolic stress or from the sympathetic nervous system [24, 25]. In vivo and in vitro, it was shown that inosine suppresses the production of pro-inflammatory cytokine and chemokine production but induces the production of the anti-inflammatory IL-10 [26].
Besides, inosine degradation produces urate which is a valuable endogenous antioxidant and an oxyradicals and peroxynitrite scavenger [27-29]. It was observed that uric acid supplementation in vivo has protective effects against shock [29] and neuroinflammation [30]. Data obtained in the present work showed an increase of $1-2 \%$ in $\mathrm{SpO} 2$ depending on the type of effort (mixed, anaerobic or aerobic) after the administration of $1 \mathrm{~g}$ inosine.

In the case of the time spent in the effort area according to tests 1 and 2, substantial increases of 8 (test 1 ) and $22 \%$ (test 2), respectively were observed, in terms of endurance, which also led to an increase in heart rate (HR).

Thus, the effort size was obtained by comparing the mean value of HR to the maximum values calculated according to the well-known Astrand formula "HR $\mathrm{Mx}=220$ - age".

For taekwondo wt practitioners, the effort grew from intense with an HR mean of $159 \mathrm{~b} / \mathrm{min}$ at maximum effort to $171 \mathrm{~b} / \mathrm{min}$. For wkf karate athletes, the effort increased from optimal with an HR mean of $155 \mathrm{~b} / \mathrm{min}$ to intense with an HR mean of $163 \mathrm{~b} / \mathrm{min}$. For the ashihara karate practitioners, the effort increased from optimal with an HR mean of $139 \mathrm{~b} / \mathrm{min}$ to intense with an HR mean of $159 \mathrm{~b} / \mathrm{min}$.

It is known that in taekwondo where the technical actions are executed in speed-strength regime, good endurance is required, and because multiple technical actions are performed, the scoring is made electronically, automatically without too much intervention from the referee.

Thus, the number of technical actions performed during a match, significantly increased for all three branches of sport namely, taekwondo wt $27 \%$, karate wkf $21 \%$ and ashihara $23 \%$. Thus, our intervention led to a 
larger enhancement for taekwondo where endurance is needed.

Williams et al. in a crossover study, assessed ergogenic properties of inosine $(6,000 \mathrm{mg} /$ day for $2 \mathrm{~d}$, orally) in terms of 3-mile run time and VO2 peak, in 9 endurance runners; results showed that inosine supplementation had no effects on the above-mentioned factors, suggesting ineffectiveness of inosine for aerobic sports [20].

Nevertheless, having in mind safety profile of inosine in humans, its anti-inflammatory properties observed in human cells [31] and in vivo [32-35], further testing of inosine in humans is suggested.

\section{Conclusions}

Administration of 1 gram of inosine, had a significant increasing effect of $24 \%$ on the competitive motor performances. In our study, according to the sport practiced, the best results were achieved for the athletes who practice a martial art of full contact type that requires a good endurance to perform technical actions in speed-force regime. Nonetheless, the least influence was observed for the motor reaction if it is not causally related to endurance. Thus, we can argue that for the athletes enrolled in the study, as a result of supplementing the effort capacity with inosine, there was an increase in the endurance and performance according to the type of competition effort.

\section{Conflict of interest}

The authors declare no conflict of interest.

\section{References}

1. Elsawy G, Abdelrahman O, Hamza A, Effect of Choline Supplementation on Rapid Weight LossandBiochemical Variables Among Female Taekwondoand Judo Athletes. J Human Kinetics, 2014; 40: 77-82.

2. Banciu A, Cosma G, Lica E, Description, evaluation and analysis of physical tests corresponding to tennis players. J Sport Kinetic Move., 2019; 34(II): 80-85.

3. Garban G, Florescu N, Guide - Dietary supplements. National Public Health Intitute, Bucharest, Romania $1^{\text {st }}$ Ed. 2013; 7, (available in Romanian).

4. EU Commission. Directive 2002/46/EC of the European Parliament and of the council of 10 June 2002 on the approximation of the laws of the Member States relating to food supplements. Official Journal of the European Communities, L183/51, 2002; https://eurlex.europa.eu.

5. Epuran M, Holdevici I, Toniţa F, Performance sport psychology. Theory and practice. FEST Publishing House, Bucharest, Romania, 2001; 37, (available in Romanian).

6. Bompa T, Buzzichelli C, Periodization: Theory and Methodology of Training, edit. Human Kinetics, Champaign, IL, 2019; 287.

7. Morgovan C, Ghibu S, Juncan AM, Rus LL, Butucă A, Vonica L, Muntean A, Moş L, Gligor F, Olah NK, Nutrivigilance: a new activity in the field of dietary supplements. Farmacia, 2019; 67(3): 537-544.
8. Antonio J, Kalman D, Stout JR, Greenwood M, Willoughby DS, Haff GG, (Eds.), Essentials of sports nutrition and supplements, Humana Press, Totowa, 2008; 61.

9. Koktavý P, Overview of food supplements used for sports nutrition. Pro Farmaceutické Asistenty, 2010; 6(6): 312-316. (available in Czech).

10. Stancu E, Tăerel AE, Soroceanu V, Rais C, Ghica $\mathrm{M}$, Ethical aspects of food supplements in EU and Romania. Farmacia, 2019; 67(4): 736-742.

11. Gholamnezhad Z, Mégarbane B, Rezaee R, Molecular Mechanisms Mediating Adaptation to Exercise. In Physical Exercise for Human Health, Springer, Singapore, 2020; 45-61.

12. Bernacikova $M$, Regeneration and nutrition of sport, $1^{\text {st }}$ Ed. Brno: Masaryk University, 2013; 250, (available in Czech).

13. Starling RD, Trappe TA, Short KR, Sheffield-Moore M, Jozsi AC, Fink WJ, Costill DL, Effect of inosine supplementation on aerobic and anaerobic cycling performance. Med Sci Sports Exerc., 1996; 28(9): 1193-1198.

14. Hargreaves M, McKenna MJ, Jenkins DG, Warmington SA, Li JL, Snow RJ, Febbraio MA, Muscle metabolites and performance during high-intensity, intermittent exercise. J Appl Physiol., 1998; 84(5): 1687-1691.

15. www.nutrend-supplements.com.

16. Drăgoi CM, Moroşan E, Dumitrescu IB, Nicolae AC, Arsene AL, Drăgănescu D, Lupuliasa D, Ioniţă AC, Pantea Stoian A, Nicolae C, Rizzo M, Mititelu M, Insights into chrononutrition: the innermost interplay amongst nutrition, metabolism and the circadian clock, in the context of epigenetic reprogramming. Farmacia, 2019; 67(4): 557-571.

17. Bucci L, Nutrients as ergogenic aids for sports and exercise, CRC Press, Boca Raton, Florida, 1993; 61.

18. Williams MH, Kreider RB, Hunter DW, Somma CT, Shall LM, Woodhouse ML, Rokitski L, Effect of inosine supplementation on 3-mile treadmill run performance and VO2 peak. Med Sci Sports Exerc., 1990; 22(4): 517-522.

19. Dragan I, Baroga M, Eremia N, Georgescu E, Studies regarding some effects of inosine in elite weightlifters. Rom J Physiol., 1993; 30(1-2): 47-50.

20. Grunewald KK, Bailey RS, Commercial lymarketed supplements for body building athletes. Sports Med., 1993; 15: 90-103.

21. McNaughton L, Dalton B, Tarr J, Inosine supplementation has no effect on aerobic or anaerobic cycling performance. Int J Sport Nutr., 1999; 9(4): 333-344.

22. Williams M, Dietary supplements and sports performance: herbals. J Int Soc Sports Nutrit., 2006; 3(1): 1-6.

23. Braun H, Koehler K, Geyer H, Kleinert J, Mester J, Schonzer W, Dietary Supplement Use among Elite Young German Athletes. Int J Sport Nutrit Exerc Metab., 2009; 19(1): 97-109.

24. Cronstein BN, Adenosine, an endogenous antiinflammatory agent. J Appl Physiol., 1994; 76: 5-13.

25. Haskö G and Szabö C, Regulation of cytokine and chemokine production by transmitters and co-transmitters of the autonomic nervous system. Biochem Pharmacol., 1998; 56: 1079-1087.

26. Haskö G, Kuhel DG, Németh ZH, Mabley JG, Stachlewitz RF, Virag L, Lohinai Z, Southan GJ, 
Salzman AL, Szabö C, Inosine inhibits inflammatory cytokine production by a posttranscriptional mechanism and protects against endotoxininduced shock. J Immunol, 2000; 64: 1013-1019.

27. Ames BN, Cathcart R, Schwiers E, Hochstein P, Uric acid provides an antioxidant defense in humans against oxidant- and radical-caused aging and cancer: a hypothesis. Proc Natl Acad Sei USA, 1981; 78: 6858-6862.

28. Becker BF, Reinholz N, Ozcelik T, Leipert B, Gerlach $\mathrm{E}$, Uric acid as radical scavenger and antioxidant in the heart. Pflugers Arch., 1989; 415: 127-135.

29. Szabö C, Zingarelli B, Salzman AL, Role of polyADP ribosyltransferase activation in the vascular contractile and energetic failure elicited by exogenous and endogenous nitric oxide and peroxynitrite. Cire Res., 1996; 78: 1051-1063.

30. Hooper DC, Bagasra O, Marini JC, Zborek A, Ohnishi ST, Kean R, Champion JM, Sarker AB, Bobroski L, Farber JL, Akaike T, Maeda H, Koprowski H, Prevention of experimental allergic encephalomyelitis by targeting nitric oxide and peroxynitrite. Proc Natl Acad Sei USA, 1997; 94: 2528-2533.
31. Marton A, Pacher P, Murthy KG, Nemeth ZH, Hasko G, Szabo C, Anti-inflammatory effects of inosine in human monocytes, neutrophils and epithelial cells in vitro. IJMMS, 2001; 8(6): 617-621.

32. Haskö G, Kuhel DG, Németh ZH, Mabley JG, Stachlewitz RF, Virag L, Lohinai Z, Southan GJ, Salzman AL, Szabö C, Inosine inhibits inflammatory cytokine production by a posttranscriptional mechanism and protects against endotoxininduced shock. $J$ Immunol., 2000; 164: 1013-1019.

33. Soriano FG, Liaudet L, Marton A, Haskö G, Lorigados $\mathrm{CB}$, Deitch EA, Szabö C, Inosine improves gut permeability and vascular reactivity in endotoxic shock. Crit Care Med., 2001; 29: 703-708.

34. Liaudet L, Mabley JG, Soriano FG, Pacher P, Marton A, Haskö G, Szabö C, Inosine reduces systemic inflammation and improves survival in septic shock induced by cecal ligation and puncture. Am J Resp Crit Care Med., 2001; 164(7): 1213-1220

35. Wakai A, Winter DC, Street JT, O'Sullivan RG, Wang $\mathrm{JH}$, Redmond HP, Inosine attenuates tourniquetinduced skeletal muscle reperfusion injury. J Surg Res., 2001; 99: 311-315. 